\title{
Influenza A (H1N1) pandemic vaccination - an underlying risk factor for many CNS complications in Brazil
}

\author{
Vacinação para pandemia de influenza (H1N1) - um fator de risco pouco reconhecido a \\ muitas complicações do sistema nervoso central no Brasil
}

\section{Dear Sir,}

The interesting paper published by Lessa et al. ${ }^{1}$ described four patients with immunological reaction against central nervous system (CNS) after influenza A (H1N1) immunization $^{1}$. A few environmental factors such as bacterial infections, viral infections, and vaccinations have been considered triggers for immune destruction of $\mathrm{CNS}^{2}$.

The influenza virus has historically been associated with cases of narcolepsy. Narcolepsy is a sleep and neurologic disease characterized by excessive daytime sleepiness, cataplexy, hallucinations, sleep paralysis, and sleep fragmentation. Recent Chinese study demonstrated a 6.7-fold increased risk of developing narcolepsy after H1N1 pandemic vaccination in 2009 . However, just Pandemrix ${ }^{\circledR}$ vaccine has been related to increased risk of narcolepsy. Pandemrix $^{\circledR}$ is a monovalent vaccine developed by GlaxoSmithKline (GSK) to influenza pandemics in 2009. GSK vaccine contains an immune adjuvant called AS03 that has the function to increase the immune response ${ }^{3}$. The association between narcolepsy and vaccination for influenza A (H1N1) during pandemic in Europe and North America was also suggested in Sweden. Likewise, studies show higher risk of narcolepsy and cataplexy after H1N1 pandemic vaccination in Sweden, Finland, and Canada ${ }^{3}$.

In Brazil, vaccination against pandemic influenza H1N1 was released in March and April 2010, and about 25\% of the population was vaccinated by Pandemrix ${ }^{\circledR} 4$. According to the Ministry of Health of Brazil, more than 24 million people were vaccinated against the H1N1 flu. The number corresponds to more than $80 \%$ of the priority group that was formed by the elderly, children, pregnant women, health professionals and populations indigenous.

An autoimmune response to development of narcolepsy or other CNS injuries can have genetic susceptibility. The higher prevalence of HLA-DQB1 ${ }^{*} 0602$, which is present in $88 \%-98 \%$ of patients with narcolepsy and cataplexy is an example. The immunological theory of narcolepsy defends an attack against hypothalamus with consequent lost of hypocretin cells ${ }^{5}$. It is possible that narcolepsy and CNS lesions described by Lessa et al. after H1N1 immunization have common immunological pathophysiology ${ }^{1}$. Should be very interesting to check which kind of H1N1 vaccine was used in these four patients.

Gustavo Bruniera Peres Fernandes ${ }^{1}$, Sergio Tufik ${ }^{1}$, Fernando Morgadinho Santos Coelho ${ }^{1,2}$

\section{References}

\footnotetext{
1. Lessa R, Castillo M, Azevedo R, Azevedo F, Azevedo H. Neurological complications after $\mathrm{H} 1 \mathrm{~N} 1$ influenza vaccination: magnetic resonance imaging findings. Arq Neuropsiquiatr. 2014;72(7):496-4. http://dx.doi. org/10.1590/0004-282X20140064

2. De la Herrán-Arita AK, García-García F. Narcolepsy as an immunemediated disease. Sleep Disord. 2014;2014:792687.10.1155/2014/ 792687

3. Kothare SV, Wiznitzer M. Association between H1N1 vaccination and narcolepsy-cataplexy: flu to sleep. Neurology. 2013;80(14):1276-7. http://dx.doi.org/10.1212/WNL.0b013e31828ab382
}

\footnotetext{
4. Ministério da Saúde. Secretaria de Vigilância em Saúde. Departamento de Vigilância Epidemiológica. Estratégia Nacional de Vacinação contra o vírus Influenza pandêmico (H1N1) 2009. Brasília DF: Ministério da Saúde; 2010 [acesso em: 15 abr 2014]. (Informe Técnico Operacional). Disponivel em: http://www.anvisa.gov.br/hotsite/ influenza/arquivos/informe_tecnico_13_03.pdf

5. Aloe F, Alves RC, Araujo JF, Azevedo A; Bacelar A, Bezerra M et al. Brazilian guidelines for the treatment of narcolepsy. Rev Bras Psiquiatr. 2010;32(3):305-14. http://dx.doi.org/10.1590/S151644462010000300016
}

${ }^{1}$ Departamento de Psicobiologia, Universidade Federal de São Paulo, Sao Paulo SP, Brazil;

${ }^{2}$ Departamento de Neurologia e Neurocirurgia, Universidade Federal de São Paulo, Sao Paulo SP, Brazil.

Correspondence: Fernando Morgadinho Santos Coelho; Rua Marselhesa, 529; 04020-060 São Paulo SP, Brasil; E-mail: fernandomorgadinho@hotmail.com Conflict of interest: There is no conflict of interest to declare.

Support: AFIP \& FAPESP- CEPID 98/14303-3.

Received 15 August 2014; Received in final form 27 August 2014; Accepted 15 September 2014. 